\title{
Priorities for Sweetpotato Research in Developing Countries: Results of a Survey
}

\author{
Keith O. Fuglie ${ }^{1}$ \\ Resources and Rural Economics Division, USDA, Economic Research \\ Service, Washington, DC 20036 \\ Additional index words. constraints analysis, global public goods, scoring model
}

\begin{abstract}
International institutions like the International Potato Center (CIP) strive to provide "global public goods" in the form of improved technologies applicable to large regions of the developing world. To identify priorities for sweetpotato improvement, CIP conducted a survey of knowledgeable scientists in developing countries to elicit their perspectives on the most important constraints facing poor and small-scale sweetpotato growers in their countries. Respondents scored productivity and other constraints according to their importance in the region or country where they worked. Mean and weighted mean scores were estimated to provide a group judgment of the most important constraints facing sweetpotato farmers in developing countries. The survey results showed that there are a few key needs facing farmers in all major sweetpotato producing areas, but there are other very important needs specific to certain regions. The needs that scored highest in all or most of the major sweetpotato producing areas in developing countries are: i) control of viruses (through varietal resistance, quality planting material, and crop management); ii) small-enterprise development for sweetpotato processing; iii) improvement in availability and quality of sweetpotato planting material; and iv) improved cultivars exhibiting high and stable yield potential. Some differences emerged, however, in priority needs of the two major centers of sweetpotato production: Additional priorities for sub-Saharan Africa include improved control of the sweetpotato weevil and cultivars with high $\beta$-carotene content to address vitamin A deficiency. For China, other top needs are: i) conservation and characterization of genetic resources; ii) prebreeding; iii) cultivars with high starch yield; and iv) new product development. The different sets of priorities reflect differences in the role of sweetpotato in the rural economy and also different capacities of the agricultural research system in these regions of the world. Compared with earlier surveys, there now seems to be a greater need for postharvest utilization research, especially in sub-Saharan Africa, partly reflecting a demand constraint due to the crop's status as an inferior food.
\end{abstract}

As an international agricultural research center, the International Potato Center (CIP) ${ }^{2}$ strives to provide global public goods in the form of improved agricultural technologies. ${ }^{3}$ To help identify research priorities, CIP has conducted surveys of persons knowledgeable about the constraints limiting sweetpotato productivity and value in developing coun- tries (CIP, 1990; Horton, 1989). However, no comprehensive survey of sweetpotato productivity constraints in developing countries has been conducted since $1990 .{ }^{4}$ Nevertheless, over the past 16 years the role of the sweetpotato in developing countries has changed significantly. China, already the largest producer in 1990, continued to wit-

\footnotetext{
Received for publication 10 Jan. 2007. Accepted for publication 8 Mar. 2007

This work was conducted while the author was a senior economist with the International Potato Center (CIP). The views expressed are the author's own and no official endorsement of the USDA should be inferred. The author thanks the many individuals who helped with the translation and distribution of the survey, especially Hubert Zandstra and Luis Salazar for their helpful comments on an earlier draft of this paper.

${ }^{1}$ To whom reprint requests should be addressed; e-mail kfuglie@ers.usda.gov

${ }^{2} \mathrm{CIP}$ is a non-profit institution that conducts agricultural research, including potato improvement, to address food security, poverty, and sustainability of natural resources for developing countries. It was established in 1971 in Lima, Peru, and is supported by the Consultative Group for International Agricultural Research (CGIAR).

${ }^{3}$ The concept of a public good is one that could not be expected to be provided by the private sector. It is a good that is freely available to all and, as in the case of knowledge, would not be diminished by use. Therefore, the provision of public goods is usually the purview of government. However, many important social problems extended beyond national borders, and single nations may be unwilling or unable to provide it in sufficient quantity. The CGIAR is an example of an international consortium being formed to address such a cross-national problem, in this case the under-supply of improved agricultural technology to developing countries (Gardner and Lesser, 2003).

${ }^{4}$ The only published account of sweetpotato research priorities in developing countries is the result of a 1987 survey for Asia (Horton, 1989). CIP conducted a global survey on sweetpotato priorities in 1990 but these results were never published. They were reviewed by the author, however, to compare with results from the current survey.
}

ness declining use of sweetpotato as a staple food but increased utilization for animal feed and industrial starch (Huang et al., 2003). Meanwhile, sub-Saharan Africa added over one million hectares to sweetpotato cultivation (FAO, 2005). Moreover, advances in biological and informational technologies have significantly enhanced the prospects of using agricultural research as a means of improving sweetpotato productivity. In addition, with agreement on the Millennium Development Goals by the United Nations, the international community has given renewed emphasis to alleviating poverty, hunger, malnutrition, disease, and other dimensions of under-development. Improving agricultural productivity in developing countries is an important part of this undertaking. For these reasons, in 2005 CIP launched a strategic planning exercise to revisit its priorities for sweetpotato improvement. As part of that exercise, CIP conducted a survey of developing country scientists to elicit their perspectives on the most important constraints facing poor and small-scale sweetpotato growers in their countries. The survey is an example of a "scoring model" for assessing research priorities (Ruttan, 1982). In this approach, scientists score productivity and other constraints according to their importance in the region or country where they work. Scores are then averaged (with the option of assigning different weights to each response) to obtain a group judgment of the priority rankings of the constraints. Other approaches to research priority setting include quantitative models like yield gap assessment and economic welfare analysis (Alston et al., 1995; Ruttan, 1982). The advantage of a qualitative scoring model is that, due to its simplicity, it allows for wide participation by scientists with diverse backgrounds. In CIP's case, it was also used to provide a "check" against an internal quantitative assessment of sweetpotato research priorities (see Fuglie, 2007) and a way for scientists from developing countries to weigh in on CIP's strategic planning process.

This paper reports the results of this survey and discusses implications for international sweetpotato research and development targeted for developing countries.

\section{Materials and Methods}

Between September and Nov. 2005, CIP sent 69 questionnaires to agricultural scientists in 29 developing countries to elicit their opinions on the most important constraints to productivity and value facing low-income sweetpotato farmers in their countries. The nonrandom sample was selected based on CIP's long history of research collaboration in these countries. In each country, we attempted to identify the leading sweetpotato researchers and research institutions. In most cases, they came from national sweetpotato programs, although some were employed at agricultural universities or provincial research institutes. For China, given the size 
and diversity of the country, questionnaires were sent to a number of provincial research institutes engaged in sweetpotato improvement. Survey respondents were also invited to pass on the questionnaire to other persons with extensive knowledge of sweetpotato in their country.

Although the purpose of the survey was to solicit perspectives of scientists from developing countries to help revise CIP's research priorities, it is worth mentioning that CIP's planning workshops, strategic plans, and other activities over the years are likely to have influenced or informed the opinion of the survey respondents. Nevertheless, the survey provides a fresh opportunity for these scientists to weigh in on priority needs in a systematic way. For established research programs, the scoring survey is a useful tool for re-examining issues where substantial progress has already been achieved as well as identifying new emerging constraints.

The questionnaire was translated into English, Spanish, Chinese, and Russian and distributed by e-mail. By the end of Jan. 2006, 36 responses had been received from 21 countries (Table 1). Scientists from Vietnam returned six questionnaires, scientists from China, five questionnaires, and other respondents from one to three questionnaires per country. The survey coverage included nearly all major sweetpotato-producing countries in Asia and eastern Africa, although it missed some producing countries in western and southern Africa as well as the Caribbean (Fig. 1).

The questionnaire included sections for describing priority needs for crop improvement (breeding), vegetative propagation, crop management (including pests, disease, soil, and water), germplasm conservation, postharvest and marketing, impact assessment, and information and communication technology. The survey questions refer to constraints to both farm productivity and crop value, as well as needs of the local sweetpotato research community (such as improved utilization of crop germplasm and scientific information). Respondents were asked to rank needs using a score of 1 (not important) to 4 (very important). In addition, respondents were asked to rank the role of CIP in addressing this need from 1 (not relevant) to 4 (very relevant). In the great majority of cases the scores for "importance" and "relevance" were very similar, so only the scores for "importance" of the need are reported here.

We tabulated the distribution of scores and calculated the mean score for each question using the entire sample and subsamples from three regions: sub-Saharan Africa (SSA), East, Southeast Asia, and the Pacific (ESEAP), and South, West, and Central Asia (SWCA). ${ }^{5}$ In addition to simple mean scores, we estimated a weighted mean score by first calculating the mean score per

\footnotetext{
${ }^{5}$ We do not report separate results for Latin America because only two questionnaires were received from this region. However, the responses from Latin America are included in the estimation of the global mean scores.
}

country (in cases where multiple responses were received from a country) and then weighting each country mean score by the sweetpotato crop area and by a measure of the prevalence of poverty in that country. Sweetpotato crop area is the average annual area harvested between 2001 and 2003 (FAO, 2005). Because we have a particular interest in identifying priority needs of sweetpotato growers living in regions with greatest poverty, we also estimated a weighted average score using crop area multiplied by the proportion of a country's population in extreme poverty (earning less than US \$1 per capita per day). Poverty statistics are from the World Bank (2005). The area-times-poverty rate weighted mean gives greater importance to countries with greater numbers of people growing sweetpotato and living in extreme poverty.

Because the responses are categorical data, mean scores ranged from a possible minimum of 1.00 to a maximum of 4.00 , with a higher score implying greater importance. Response rates varied by question, as not all respondents answered all questions. Further, for several questions, such as on the importance of pests and diseases, respondents were asked to name the particular species important to sweetpotato farmers in their countries. When several respondents mentioned a particular pest or disease, we report the mean score for those responses. We also calculated the standard error of the means. For most, standard errors are $\approx 0.15$, implying a $95 \%$

HortScience Vol. 42(5) August 2007

Table 1. Questionnaires sent and received from sweetpotato scientists in developing countries.

\begin{tabular}{lcccc}
\hline Region & Questionnaires sent & Countries & Questionnaires received & Countries \\
\hline East, Southeast & 33 & 10 & 20 & 9 \\
Asia, and the Pacific (ESEAP) & & & & \\
Latin America and & 6 & 5 & 2 & 2 \\
$\quad$ Caribbean (LAC) & 19 & 9 & 9 & 7 \\
Sub-Saharan Africa (SSA) & & & & \\
South, West, and & 11 & 5 & 5 & 21 \\
$\quad$ Central Asia (SWCA) & 69 & 29 & 36 & \\
All & & &
\end{tabular}

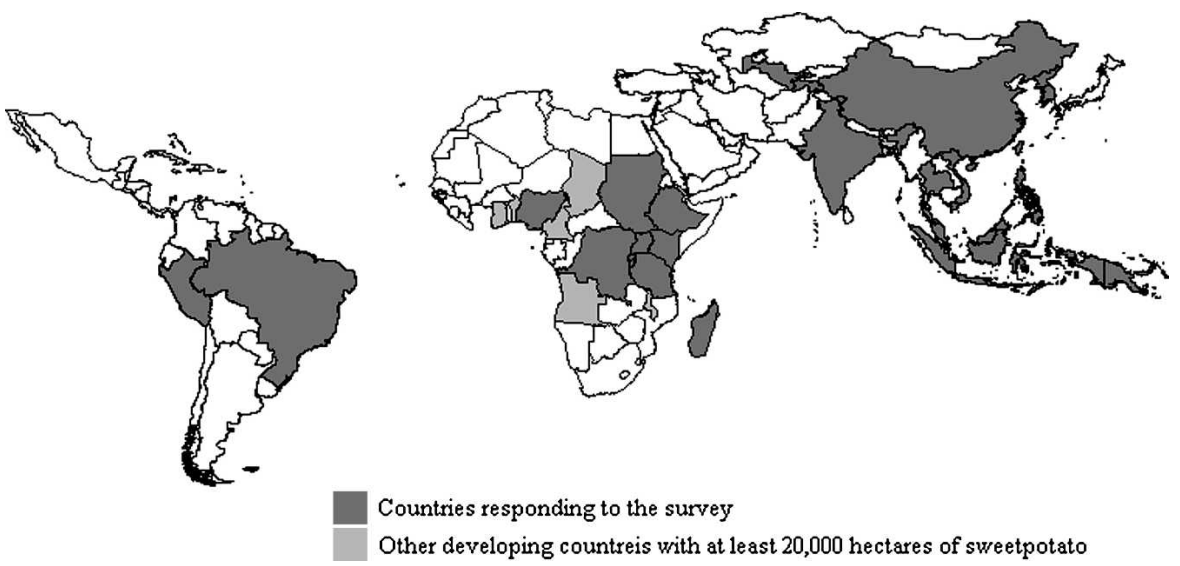

Fig. 1. Survey of priority needs of sweetpotato farmers in developing countries.

confidence interval around a mean score of $\mathrm{X}$ would be $X \pm 0.3$. As a general rule of thumb, we view mean scores differing by $>0.3$ to be significantly apart.

\section{Results}

We report the results from our survey in six sections. The first five sections report the unweighted rankings for priority needs by the entire sample and by respondents from the three regions. The sixth section examines how weighting the survey responses by national crop area and poverty affect the rankings for global sweetpotato research priorities.

1. Priority needs for sweetpotato crop improvement (breeding). Table 2 shows the survey results ranking priority needs for sweetpotato crop improvement. The most important need expressed by survey respondents was new cultivars with stable and high yield acceptable for local consumption. Historically, sweetpotato in developing countries has not received much attention from national or international research (CIP only began to work on sweetpotato in 1985), and farmers in most developing countries still rely on traditional landraces. The important exception is China, where sweetpotato breeding has a longer history and where modern varieties have been widely adopted by farmers (Fuglie et al., 2002). For the rest of Asia and most of Africa, there has been little modern genetic improvement in cultivated varieties. The need for prebreeding (genetic enhancement of parental breeding lines) was also ranked high, especially by respondents from Asia. 
For specific traits, priority needs receiving an average global score of at least 3.00 include earliness (which we interpret as early bulking), virus resistance, drought tolerance, improved nutrition (especially higher levels of $\beta$-carotene, a precursor to vitamin A), insect resistance, and higher dry matter yield (primarily for starch and flour processing).

Regionally, the rankings for sweetpotato crop improvement constraints tended to score highest in sub-Saharan Africa. Sweetpotato has emerged as one of the most important subsistence crops in many parts of the African continent, especially in the countries surrounding Lake Victoria. It is often grown by female farmers on poor, marginal soil and harvested in piece-meal fashion to meet daily food needs of the household (Woolfe, 1992). The need for improved nutritional content in sweetpotato received the same high score (3.67) as virus resistance and earliness as the most important crop traits sought for Africa. For nutritional content, almost all respondents from Africa named $\beta$-carotene as the desired trait. Although sweetpotato can offer some of the highest food sources of $\beta$-carotene, most cultivated varieties in Africa are of the white-flesh type, and vitamin A deficiency is common among the rural poor (Low et al., 2001). In addition, respondents from Africa mentioned the importance of varieties adapted to marginal soils (acid soils and water-logged soils being the most frequently named soil conditions). Also very important to Africa was insect stress, caused primarily by the sweetpotato weevil (Cylas brunneus and Cylas puncticolis). Finally, African respondents mentioned a need for varieties suitable for use as livestock feed, which implies not only high root yield but also high vine yield for fodder.

2. Priority needs for sweetpotato propagation. In developing countries, sweetpotato is propagated vegetatively using vine cuttings, roots, and slips (shoots emerging from roots). In tropical environments where some sweetpotato plants can be kept in the field year-round, crop multiplication is done almost exclusively with vine cuttings. Over time, viruses tend to accumulate in this planting material and can severely limit plant vigor and root yield. Few countries have developed systems for mass propagation and distribution of disease-free planting material for sweetpotato, and the need for improvements in availability, quality, distribution and storage of planting material was ranked high by survey respondents (Table 3 ). China is one of the few countries that has successfully applied mass propagation of disease-free planting material and achieved impressive improvements in yield as a result (Fuglie et al., 1999). As was the case for crop improvement needs, the importance of propagation constraints was ranked highest by respondents from sub-Saharan Africa relative to the other regions.

3. Priority needs for sweetpotato crop management. Closely related to crop and propagation improvement, but encompassing a broader set of technology options, are needs for improved management of crop pests, diseases, soil and water resources, and production systems. This could include new methods of field cultivation and tillage, fertilizer and pesticide application, as well as the use of improved planting material and varieties. Our survey focused on identifying

Table 2. Priority needs for sweetpotato crop improvement (breeding). ${ }^{\mathrm{z}, \mathrm{y}}$

\begin{tabular}{|c|c|c|c|c|c|c|c|c|c|c|}
\hline & \multicolumn{4}{|c|}{$\begin{array}{c}\text { All responses } \\
\text { No. of responses ranking importance }(1-4)\end{array}$} & \multirow[b]{2}{*}{$\begin{array}{l}\text { Total } \\
\text { responses }\end{array}$} & \multicolumn{2}{|c|}{ All regions } & \multirow{2}{*}{$\begin{array}{c}\text { SSA } \\
\text { Mean } \\
\text { rank }\end{array}$} & \multirow{2}{*}{$\begin{array}{c}\text { ESEAP } \\
\text { Mean } \\
\text { rank }\end{array}$} & \multirow{2}{*}{$\begin{array}{c}\text { SWCA } \\
\text { Mean } \\
\text { rank }\end{array}$} \\
\hline & $\begin{array}{c}1, \text { Not } \\
\text { important }\end{array}$ & $\begin{array}{c}\text { 2, Low } \\
\text { importance }\end{array}$ & $\begin{array}{c}3, \\
\text { Important }\end{array}$ & $\begin{array}{l}4, \text { Very } \\
\text { important }\end{array}$ & & $\begin{array}{c}\text { Mean } \\
\text { rank }\end{array}$ & $\begin{array}{c}\text { SEM } \\
\text { (mean) }\end{array}$ & & & \\
\hline \multicolumn{11}{|l|}{ Yield and quality } \\
\hline Stable, high yield, \& consumer acceptance & 0 & 3 & 12 & 21 & 36 & 3.50 & 0.11 & 3.56 & 3.52 & 3.20 \\
\hline Prebreeding & 0 & 5 & 13 & 15 & 33 & 3.30 & 0.13 & 3.00 & 3.37 & 3.50 \\
\hline Improved nutrition & 1 & 4 & 17 & 14 & 36 & 3.22 & 0.13 & 3.67 & 3.05 & 3.00 \\
\hline High dry matter/starch/flour yield & 0 & 7 & 16 & 13 & 36 & 3.17 & 0.12 & 2.56 & 3.43 & 3.00 \\
\hline High root \& vine yield for animal feed & 1 & 9 & 17 & 8 & 35 & 2.91 & 0.13 & 3.33 & 2.90 & 2.80 \\
\hline \multicolumn{11}{|l|}{ Biotic stress } \\
\hline Viruses & 0 & 4 & 16 & 16 & 36 & 3.33 & 0.11 & 3.67 & 3.24 & 3.00 \\
\hline Insects & 1 & 4 & 16 & 14 & 35 & 3.23 & 0.13 & 3.50 & 3.10 & 3.20 \\
\hline Nematodes & 7 & 12 & 10 & 5 & 34 & 2.38 & 0.17 & 2.63 & 2.20 & 2.60 \\
\hline Other biotic stress & 0 & 1 & 5 & 3 & 9 & 3.22 & 0.22 & & & \\
\hline \multicolumn{11}{|l|}{ Abiotic Stress } \\
\hline Drought tolerance & 1 & 2 & 18 & 15 & 36 & 3.31 & 0.12 & 3.56 & 3.19 & 3.20 \\
\hline Marginal soil tolerance & 2 & 6 & 18 & 8 & 34 & 2.94 & 0.14 & 3.50 & 2.85 & 2.80 \\
\hline Cold tolerance & 13 & 9 & 9 & 3 & 34 & 2.06 & 0.17 & 1.63 & 2.20 & 2.40 \\
\hline Other abiotic stress & 0 & 0 & 3 & 0 & 3 & 3.00 & 0.00 & & & \\
\hline \multicolumn{11}{|l|}{ Environmental adaptation } \\
\hline Earliness & 1 & 3 & 11 & 21 & 36 & 3.44 & 0.13 & 3.67 & 3.38 & 3.60 \\
\hline Shade tolerance & 5 & 13 & 12 & 4 & 34 & 2.44 & 0.15 & 2.78 & 2.32 & 2.60 \\
\hline Other & 0 & 0 & 6 & 1 & 7 & 3.14 & 0.14 & & & \\
\hline
\end{tabular}

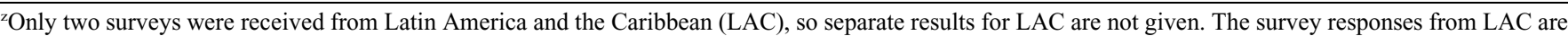
reported in the total for all regions, however.

${ }^{y}$ Source: author's survey.

Table 3. Priority needs for sweetpotato propagation. ${ }^{\mathrm{z}, \mathrm{y}, \mathrm{x}}$

\begin{tabular}{|c|c|c|c|c|c|c|c|c|c|c|}
\hline & \multicolumn{4}{|c|}{$\begin{array}{l}\text { All responses } \\
\text { No. of responses ranking importance }(1-4)\end{array}$} & \multirow[b]{2}{*}{$\begin{array}{l}\text { Total } \\
\text { responses }\end{array}$} & \multicolumn{2}{|c|}{ All regions } & \multirow{2}{*}{$\begin{array}{c}\text { SSA } \\
\text { Mean } \\
\text { rank }\end{array}$} & \multirow{2}{*}{$\begin{array}{c}\text { ESEAP } \\
\text { Mean } \\
\text { rank }\end{array}$} & \multirow{2}{*}{$\begin{array}{c}\text { SWCA } \\
\text { Mean } \\
\text { rank }\end{array}$} \\
\hline & $\begin{array}{c}1, \text { Not } \\
\text { important }\end{array}$ & $\begin{array}{l}2, \text { Low } \\
\text { importance }\end{array}$ & $\begin{array}{c}3, \\
\text { Important }\end{array}$ & $\begin{array}{l}\text { 4, Very } \\
\text { important }\end{array}$ & & $\begin{array}{c}\text { Mean } \\
\text { rank }\end{array}$ & $\begin{array}{c}\text { SEM } \\
\text { (mean) }\end{array}$ & & & \\
\hline Quality (disease elimination, etc.) & 0 & 1 & 9 & 25 & 35 & 3.69 & 0.09 & 4.00 & 3.67 & 3.40 \\
\hline Availability & 1 & 3 & 14 & 17 & 35 & 3.34 & 0.13 & 3.75 & 3.33 & 3.00 \\
\hline \multicolumn{11}{|l|}{ Propagation systems } \\
\hline (distribution, regulation) & 1 & 1 & 21 & 11 & 34 & 3.24 & 0.11 & 3.38 & 3.29 & 2.75 \\
\hline Storage & 1 & 6 & 16 & 10 & 33 & 3.06 & 0.14 & 3.43 & 3.05 & 3.00 \\
\hline Other & 0 & 0 & 1 & 0 & 1 & 3.00 & & & & \\
\hline
\end{tabular}

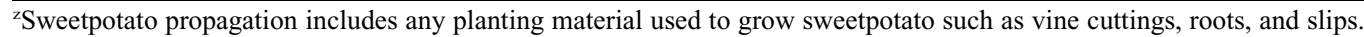

y Only two surveys were received from Latin America and the Caribbean (LAC), so separate results for LAC are not given. The survey responses from LAC are reported in the total for all regions, however.

'Source: author's survey. 
the key productivity constraints that respondents thought could be addressed through improvements in crop management, but not on what the specific components of those technologies should be. The priority rankings for two crop management categories ("Pest \& Disease Control \& Management" and "Production \& Resource Management") are shown in Table 4.

Methods to control virus and insect pests ranked as the two most important crop management needs for sweetpotato in developing countries, according to our survey. Sweetpotato weevils (Cylas formicarius in Asia and Latin America and C. brunneus and C. puncticolis in Africa) were by far the most important insect pests globally and were Africa's highest ranked need for improved crop management. Efforts to develop integrated weevil management have been successful in the Caribbean (Maza et al., 2000), although this has proven more challenging in the case of Africa (Smit and Odongo, 1997). So far, research indicates that the viruses of most economic importance include sweetpotato chlorotic stunt virus (SPCSV) that together with the ubiquitous sweetpotato feathery mottle virus (SPFMV) cause the most devastating disease, especially in subSaharan Africa and Latin America. Other interactions of SPFMV with yet-unidentified viruses are suspected to occur in western Africa, Southeast Asia, China, and the Caribbean (Moyer and Salazar, 1989; Gibson et al., 1996; L.F. Salazar, personal communication, 2005).

Priority needs for production and resource management included improved management of soil fertility and sweetpotato cropping systems. Improved water management was mentioned as an important need in Asia, as was management of soil salinity in South Asia.

4. Priority needs for postharvest utilization and marketing. Most sweetpotato produced in developing countries never leaves the farm. It is either consumed by the farm family or fed to livestock. In many countries sweetpotato is viewed as a poor person's food or even a famine food: what you eat when you can't afford anything else (Woolfe, 1992). The low status and limited market opportunities for sweetpotato give rise to a strong need expressed by survey respondents to improve postharvest utilization and marketing of the crop. These survey results are reported in Table 5 .

New food products, small enterprise development, and improvements to marketing systems were ranked as the most important postharvest needs of sweetpotato. These needs are likely complementary to each other to maximize impact of market development for low-income farmers. In other words, survey respondents saw a need not only for new food products but also for strong postharvest linkages to the rural economy and employment. Next in importance were the needs for improved methods of ware storage appropriate for small-scale farmers and better ways of using sweetpotato for animal feed. Respondents from the SSA and ESEAP regions also identified an important need for policy reform to promote improved utilization and marketing of sweetpotato.

5. Other priority needs for sweetpotato improvement. The survey asked respondents to rank a number of other issues related to improvement of sweetpotato productivity in their countries, including genetic resource management, evidence of impact of sweetpotato technology and research investments, and capacities of the sweetpotato research and extension systems in information and communication technologies (ICT). Responses to these questions are summarized in Table 6.

For sweetpotato genetic resources, improved characterization was ranked as an important need in every region. Ex situ conservation was generally seen as a higher-priority need than in situ conservation. In addition, better capacity to manage intellectual property rights over sweetpotato genetic resources is emerging as an important issue in a number of countries.

Respondents expressed a need for more empirical evidence on how improvements in sweetpotato technology affected poverty and on the economic rate of return to public investments in sweetpotato research. Such evidence can be useful in building public support for research programs as well as in research planning. Evaluating health and environmental risks of pesticide use on sweetpotato was not seen as a major priority, probably because pesticide applications on sweetpotato are generally low compared with other crops.

Improving access to scientific knowledge and better ability to communicate research results to target audiences were ranked as important ICT needs by most survey respondents, especially those from sub-Saharan Africa. Internet-based communication and learning tools were more important for Asia than Africa, perhaps because of the greater availability of reliable internet access in Asia.

6. How weighting responses by crop area and poverty affects rankings of priorities for sweetpotato improvement. The renewed emphasis given to poverty reduction by the international community (expressed, for example, in the United Nations declaration of the Millennium Development Goals to halve the world's poverty rate by 2020) has led the international agricultural research community to search for ways to bring agricultural science more directly to the benefit of the very poor (see CIP, 2004, for example). But is there a "pro-poor" research strategy specifically for the needs of lowincome sweetpotato farmers? One way to try to identify a "pro-poor" research strategy is to give priority attention to the constraints

Table 4. Priority needs for sweetpotato crop management. ${ }^{z, y}$

\begin{tabular}{|c|c|c|c|c|c|c|c|c|c|c|}
\hline & \multicolumn{4}{|c|}{$\begin{array}{l}\text { All responses } \\
\text { No. of responses ranking importance }(1-4)\end{array}$} & \multirow[b]{2}{*}{$\begin{array}{l}\text { Total } \\
\text { responses }\end{array}$} & \multicolumn{2}{|c|}{ All Regions } & \multirow{2}{*}{$\begin{array}{c}\text { SSA } \\
\text { Mean } \\
\text { rank }\end{array}$} & \multirow{2}{*}{$\begin{array}{c}\text { ESEAP } \\
\text { Mean } \\
\text { rank }\end{array}$} & \multirow{2}{*}{$\begin{array}{c}\text { SWCA } \\
\text { Mean } \\
\text { rank }\end{array}$} \\
\hline & $\begin{array}{c}1, \text { Not } \\
\text { important }\end{array}$ & $\begin{array}{l}\text { 2, Low } \\
\text { importance }\end{array}$ & $\begin{array}{c}3, \\
\text { Important }\end{array}$ & $\begin{array}{c}\text { 4, Very } \\
\text { important }\end{array}$ & & $\begin{array}{c}\text { Mean } \\
\text { rank }\end{array}$ & $\begin{array}{c}\text { SEM } \\
\text { (mean) }\end{array}$ & & & \\
\hline \multicolumn{11}{|c|}{ Pest \& disease control \& management } \\
\hline Viruses & 0 & 3 & 13 & 19 & 35 & 3.46 & 0.11 & 3.50 & 3.52 & 3.00 \\
\hline Insects & 2 & 3 & 9 & 21 & 35 & 3.31 & 0.18 & & & \\
\hline Sweetpotato weevil & 4 & 4 & 6 & 20 & 34 & 3.24 & 0.18 & 3.78 & 3.00 & 3.00 \\
\hline Other insects or mites & 4 & 5 & 18 & 4 & 31 & 2.71 & 1.18 & 2.75 & 2.74 & 2.00 \\
\hline Fungal & 4 & 8 & 13 & 9 & 34 & 2.79 & 0.17 & 2.71 & 2.95 & 2.00 \\
\hline Nematodes & 5 & 11 & 12 & 4 & 32 & 2.47 & 0.16 & 2.33 & 2.43 & 2.75 \\
\hline Bacterial & 4 & 13 & 11 & 2 & 30 & 2.37 & 0.15 & 2.40 & 2.42 & 2.00 \\
\hline \multicolumn{11}{|c|}{ Production \& resource management } \\
\hline Soil fertility & 1 & 3 & 23 & 9 & 36 & 3.11 & 0.11 & 3.33 & 3.05 & 3.20 \\
\hline Cropping systems & 1 & 6 & 17 & 11 & 35 & 3.09 & 0.13 & 3.33 & 3.14 & 2.50 \\
\hline Water management & 3 & 5 & 19 & 7 & 34 & 2.88 & 0.14 & 2.63 & 3.00 & 3.00 \\
\hline Harvesting methods & 3 & 9 & 15 & 9 & 36 & 2.83 & 0.15 & 2.78 & 2.95 & 2.40 \\
\hline Soil salinity & 4 & 16 & 11 & 3 & 34 & 2.38 & 0.14 & 2.00 & 2.33 & 3.20 \\
\hline Soil acidity & 4 & 16 & 14 & 1 & 35 & 2.34 & 0.12 & 2.75 & 2.24 & 2.40 \\
\hline Other & 0 & 0 & 1 & 0 & 1 & 3.00 & & & & \\
\hline
\end{tabular}

${ }^{\mathrm{z}}$ Only two surveys were received from Latin America and the Caribbean (LAC), so separate results for LAC are not given. The survey responses from LAC are reported in the total for all regions, however.

'Source: author's survey. 


\begin{tabular}{|c|c|c|c|c|c|c|c|c|c|c|}
\hline & \multicolumn{4}{|c|}{$\begin{array}{c}\text { All responses } \\
\text { No. of responses ranking importano }\end{array}$} & \multirow[b]{2}{*}{$\begin{array}{c}\text { Total } \\
\text { responses }\end{array}$} & \multicolumn{2}{|c|}{ All regions } & \multirow{2}{*}{$\begin{array}{c}\text { SSA } \\
\text { Mean } \\
\text { rank }\end{array}$} & \multirow{2}{*}{$\begin{array}{c}\text { ESEAP } \\
\text { Mean } \\
\text { rank }\end{array}$} & \multirow{2}{*}{$\begin{array}{c}\text { SWCA } \\
\text { Mean } \\
\text { rank }\end{array}$} \\
\hline & $\begin{array}{c}1, \text { Not } \\
\text { important }\end{array}$ & $\begin{array}{l}2, \text { Low } \\
\text { importance }\end{array}$ & $\begin{array}{c}3, \\
\text { Important }\end{array}$ & $\begin{array}{c}\text { 4, Very } \\
\text { important }\end{array}$ & & $\begin{array}{c}\text { Mean } \\
\text { rank }\end{array}$ & $\begin{array}{c}\text { SEM } \\
(\text { mean) }\end{array}$ & & & \\
\hline New food products & 0 & 2 & 13 & 20 & 35 & 3.51 & 0.10 & 3.25 & 3.57 & 3.60 \\
\hline Small-enterprise processing methods & 1 & 0 & 15 & 20 & 36 & 3.50 & 0.11 & 3.67 & 3.52 & 3.20 \\
\hline Marketing systems & 1 & 2 & 11 & 21 & 35 & 3.49 & 0.13 & 3.78 & 3.43 & 3.25 \\
\hline Ware storage & 0 & 5 & 16 & 15 & 36 & 3.28 & 0.12 & 3.44 & 3.33 & 3.00 \\
\hline Animal feed utilization & 1 & 8 & 17 & 10 & 36 & 3.00 & 0.13 & 3.00 & 3.05 & 3.20 \\
\hline Policy reform & 2 & 6 & 20 & 7 & 35 & 2.91 & 0.13 & 3.00 & 3.00 & 2.40 \\
\hline Other & 2 & 0 & 1 & 3 & 6 & 2.83 & 0.60 & & & \\
\hline
\end{tabular}

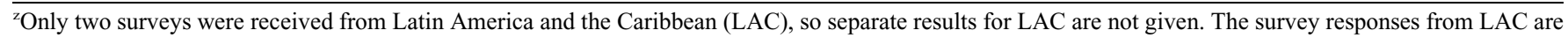
reported in the total for all regions, however.

ySource: author's survey.

Table 6. Other priority needs for potato development. ${ }^{z, y}$

\begin{tabular}{|c|c|c|c|c|c|c|c|c|c|c|}
\hline & \multicolumn{4}{|c|}{$\begin{array}{l}\text { All responses } \\
\text { No. of responses ranking importance }(1-4)\end{array}$} & \multirow[b]{2}{*}{$\begin{array}{l}\text { Total } \\
\text { responses }\end{array}$} & \multicolumn{2}{|c|}{ All regions } & \multirow{2}{*}{$\begin{array}{c}\text { SSA } \\
\text { Mean } \\
\text { rank }\end{array}$} & \multirow{2}{*}{$\begin{array}{c}\text { ESEAP } \\
\text { Mean } \\
\text { rank }\end{array}$} & \multirow{2}{*}{$\begin{array}{c}\text { SWCA } \\
\text { Mean } \\
\text { rank }\end{array}$} \\
\hline & $\begin{array}{c}1, \text { Not } \\
\text { important }\end{array}$ & $\begin{array}{c}\text { 2, Low } \\
\text { importance }\end{array}$ & $\begin{array}{c}3, \\
\text { Important }\end{array}$ & $\begin{array}{c}4, \text { Very } \\
\text { important }\end{array}$ & & $\begin{array}{c}\text { Mean } \\
\text { rank }\end{array}$ & $\begin{array}{c}\text { SEM } \\
\text { (mean) }\end{array}$ & & & \\
\hline \multicolumn{11}{|l|}{ Genetic resources } \\
\hline Characterization & 2 & 2 & 12 & 20 & 36 & 3.39 & 0.14 & 3.22 & 3.48 & 3.40 \\
\hline Ex situ conservation & 1 & 4 & 18 & 13 & 36 & 3.19 & 0.12 & 3.33 & 3.24 & 2.80 \\
\hline Intellectual property rights management & 5 & 5 & 17 & 8 & 35 & 2.80 & 0.16 & 2.88 & 3.00 & 2.20 \\
\hline In situ conservation & 4 & 7 & 16 & 8 & 35 & 2.80 & 0.16 & 2.78 & 2.95 & 2.40 \\
\hline Other & 0 & 1 & 1 & 4 & 6 & 3.50 & 0.34 & & & \\
\hline \multicolumn{11}{|l|}{ Impact assessment } \\
\hline Technology impact on poverty & 3 & 2 & 16 & 13 & 34 & 3.15 & 0.15 & 3.38 & 2.95 & 3.50 \\
\hline Economic returns to research & 1 & 5 & 17 & 10 & 33 & 3.09 & 0.13 & 3.25 & 3.10 & 3.00 \\
\hline Health and environmental risk of pesticides & 4 & 10 & 15 & 4 & 33 & 2.58 & 0.15 & 2.13 & 2.75 & 2.75 \\
\hline \multicolumn{11}{|l|}{ Information \& communication skills } \\
\hline Capacities in information \& communication & 1 & 3 & 18 & 12 & 34 & 3.21 & 0.13 & 3.50 & 3.25 & 2.60 \\
\hline Communicating to target audiences & 2 & 4 & 17 & 12 & 35 & 3.11 & 0.14 & 3.33 & 3.10 & 2.80 \\
\hline Internet-based learning modules & 2 & 6 & 17 & 9 & 34 & 2.97 & 0.14 & 2.50 & 3.10 & 3.40 \\
\hline
\end{tabular}

${ }^{\mathrm{z}}$ Only two surveys were received from Latin America and the Caribbean (LAC), so separate results for LAC are not given. The survey responses from LAC are reported in the total for all regions, however.

'Source: author's survey.

faced by large numbers of small-scale farmers in very poor countries or regions. Thus, weighting the country-average responses by the sweetpotato area and poverty rate of that country may give different global mean rankings of farmer needs than the simple average scores reported above. Weighting the survey responses by national sweetpotato area and poverty rates gives higher weight to survey responses from China and subSaharan Africa. Of the countries included in the survey, China accounted for $70 \%$ of total sweetpotato area, other Asian countries 9\%, sub-Saharan Africa countries 19\%, and Latin American countries the remaining 2\%. When scores are weighted by area $\times$ poverty, the weight given to sub-Saharan African countries increased to $50 \%$ of the total, with the weight for China at $45 \%$, and other Asia countries at $4.7 \%$ (and the remaining $0.3 \%$ for Latin America).

Table 7 compares the priority needs for sweetpotato using the weighted and unweighted global mean rankings. We have grouped the needs into three categories: topranked priorities received a mean score of at least 3.40, second-ranked priorities received a mean score between 3.00 and 3.39, and third-ranked priorities scored below 3.00 (roughly one-third of the listed needs fall into each category).
Some important changes in priorities result from including weights for sweetpotato area and poverty. For crop improvement, drought tolerance and virus resistance joined stable and high yielding varieties and earliness as top-ranked priority needs when responses are weighted by crop area and poverty. For sweetpotato propagation constraints, improving the availability of sweetpotato planting material also increased in importance, joining the need for disease-free planting material as top-ranked priorities. For crop management, improved control of viruses remained the top-ranked need but increased in its score when weighted by area $x$ poverty. The mean scores increased for postharvest utilization and marketing as well, especially small enterprise development, marketing system improvements, policy reform, and ware storage methods. Area $x$ poverty weights also increased the score for improved genetic resource characterization and ex situ conservation. However, none of the listed needs for communication and information technologies or impact assessment ranked among the most important needs for sweetpotato improvement under any of the weighting methods.

What does this suggest for the content of a "pro-poor" development agenda for sweetpotato? One issue is whether technologies to address these needs are accessible to farmers who may have few financial resources and grow sweetpotato on only very small plots. Most of the technologies identified in the survey appear to be scale-neutral, meaning that they could be profitably adopted by farmers growing very small sweetpotato plots as well as large-scale sweetpotato growers. Another issue is whether increases in farm productivity would actually translate into higher incomes for farmers. Without strong market demand, increases in productivity, if adopted widely, could lead to oversupply and a corresponding fall in market price, thereby reducing income benefits of new technologies to farmers. This concern was clearly on the minds of survey respondents who recognized the need to develop new uses and markets for the crop. However, a rigorous assessment of this issue would require an economic model that could explicitly account for market demand and price effects of technological change (see Fuglie, 2007, for an example of such a model). Further, we should note that the record of public-sector research to expand market utilization of sweetpotato in either developed or developing countries has not been very impressive (Walker and Fuglie, 2006). Expanding the utilization of sweetpotato through public research will likely require strong linkages 


\begin{tabular}{|c|c|c|c|c|c|c|}
\hline \multirow[b]{2}{*}{ Priority } & \multicolumn{2}{|c|}{ Poverty $\times$ area weighted } & \multicolumn{2}{|c|}{ Area weighted } & \multicolumn{2}{|c|}{ Unweighted } \\
\hline & Mean rank & Priority group & Mean rank & Priority group & Mean rank & Priority group \\
\hline \multicolumn{7}{|l|}{ Crop improvement } \\
\hline Stable, high yield, \& consumer acceptance & 3.55 & 1 & 3.48 & 1 & 3.50 & 1 \\
\hline Drought tolerance & 3.53 & 1 & 3.34 & 2 & 3.31 & 2 \\
\hline Earliness & 3.52 & 1 & 3.43 & 1 & 3.44 & 1 \\
\hline Virus resistance & 3.49 & 1 & 3.39 & 2 & 3.33 & 2 \\
\hline Insect resistance & 3.39 & 2 & 3.03 & 2 & 3.23 & 2 \\
\hline Prebreeding & 3.28 & 2 & 3.46 & 1 & 3.30 & 2 \\
\hline High root \& vine yield for animal feed & 3.27 & 2 & 3.09 & 2 & 2.91 & 3 \\
\hline Marginal soil tolerance & 3.18 & 2 & 2.92 & 3 & 2.94 & 3 \\
\hline Improved nutrition & 3.16 & 2 & 2.99 & 2 & 3.22 & 2 \\
\hline Nematode resistance & 3.13 & 2 & 2.91 & 3 & 2.38 & 3 \\
\hline High dry matter/starch/flour yield & 3.05 & 2 & 3.36 & 2 & 3.17 & 2 \\
\hline Shade tolerance & 2.74 & 3 & 2.49 & 3 & 2.44 & 3 \\
\hline Cold tolerance & 1.58 & 3 & 1.87 & 3 & 2.06 & 3 \\
\hline \multicolumn{7}{|l|}{ Planting material } \\
\hline Availability & 3.56 & 1 & 3.42 & 1 & 3.34 & 2 \\
\hline Quality (disease elimination, etc.) & 3.49 & 1 & 3.33 & 2 & 3.69 & 1 \\
\hline Storage & 3.31 & 2 & 3.07 & 2 & 3.06 & 2 \\
\hline Propagation systems (distribution, regulation) & 3.17 & 2 & 3.07 & 2 & 3.24 & 2 \\
\hline \multicolumn{7}{|l|}{ Crop management } \\
\hline Viruses & 3.70 & 1 & 3.58 & 1 & 3.46 & 1 \\
\hline Cropping systems & 3.31 & 2 & 3.20 & 2 & 3.09 & 2 \\
\hline Soil fertility & 3.25 & 2 & 2.87 & 3 & 3.11 & 2 \\
\hline Harvesting methods & 3.19 & 2 & 2.89 & 3 & 2.83 & 3 \\
\hline Insects & 3.17 & 2 & 2.68 & 2 & 3.31 & 2 \\
\hline Water management & 2.92 & 3 & 2.92 & 3 & 2.88 & 3 \\
\hline Fungal & 2.80 & 3 & 3.02 & 2 & 2.79 & 3 \\
\hline Nematodes & 2.66 & 3 & 2.56 & 3 & 2.47 & 3 \\
\hline Bacterial & 2.50 & 3 & 2.80 & 3 & 2.37 & 3 \\
\hline Soil acidity & 2.31 & 3 & 2.35 & 3 & 2.34 & 3 \\
\hline Soil salinity & 2.14 & 3 & 2.41 & 3 & 2.38 & 3 \\
\hline \multicolumn{7}{|l|}{ Postharvest \& marketing } \\
\hline Small enterprise processing methods & 3.65 & 1 & 3.63 & 1 & 3.50 & 1 \\
\hline Marketing systems & 3.57 & 1 & 3.36 & 2 & 3.49 & 1 \\
\hline Policy reform & 3.45 & 1 & 3.34 & 2 & 2.91 & 3 \\
\hline Ware storage & 3.42 & 1 & 3.35 & 2 & 3.28 & 2 \\
\hline New food products & 3.36 & 2 & 3.41 & 1 & 3.51 & 1 \\
\hline Animal feed utilization & 3.03 & 2 & 2.91 & 3 & 3.00 & 2 \\
\hline \multicolumn{7}{|l|}{ Genetic resources } \\
\hline Characterization & 3.49 & 1 & 3.67 & 1 & 3.39 & 2 \\
\hline Ex situ conservation & 3.46 & 1 & 3.51 & 1 & 3.19 & 2 \\
\hline Intellectual property rights management & 2.69 & 3 & 2.89 & 3 & 2.80 & 3 \\
\hline In situ conservation & 2.59 & 3 & 2.87 & 3 & 2.80 & 3 \\
\hline \multicolumn{7}{|l|}{ Impact assessment } \\
\hline Economic returns to research & 3.00 & 2 & 2.67 & 3 & 3.09 & 2 \\
\hline Technology impact on poverty & 2.81 & 3 & 2.72 & 3 & 3.15 & 2 \\
\hline Health and environmental risk of pesticides & 2.67 & 3 & 2.46 & 3 & 2.58 & 3 \\
\hline \multicolumn{7}{|l|}{ Information \& communication skills } \\
\hline Communicating to target audiences & 3.31 & 2 & 3.31 & 2 & 3.11 & 2 \\
\hline Capacities in information \& communication & 3.26 & 2 & 3.34 & 2 & 3.21 & 2 \\
\hline Internet-based learning modules & 2.61 & 3 & 2.83 & 3 & 2.97 & 3 \\
\hline
\end{tabular}

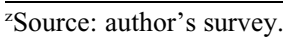

to the private sector as well as commiserate improvements in farm productivity so the crop can be a low-cost and competitive source of raw material for industry.

\section{Conclusions}

The scoring model used to derive priorities for sweetpotato improvement for developing countries proved to be a relatively low-cost method of canvassing a wide spectrum of views from knowledgeable experts of the crop. The response rate was enhanced by translation of the survey into four major languages and widespread access to electronic communications by the global agricultural research community.
What emerges from this survey of priority needs of sweetpotato farmers in developing countries is that there are some key needs facing farmers globally and that there are other very important needs specific to certain regions. First, the needs that scored high in all or most of the major sweetpotato producing areas in developing countries are

1. control of viruses (through varietal resistance, quality planting material, and crop management);

2. small-enterprise development for sweetpotato processing;

3. improvement in availability and quality of sweetpotato planting material;

4. improved cultivars exhibiting high and stable yield potential;
5. early-bulking cultivars;

6. reform of agricultural and food policies; and

7. improvement of ware storage methods.

Considering the importance to sweetpotato for poverty alleviation gives precedence to priorities of two centers of sweetpotato production: China and sub-Saharan Africa. These two regions account for $\approx 87 \%$ of the sweetpotato harvested area in developing countries and $\approx 95 \%$ of the poverty-weighted harvested area. While both of these regions indicate that the above-listed needs are of high priority, some importance differences between these regions were evident in the survey. Respondents from sub-Saharan Africa had a long list of high-priority needs 
for sweetpotato in addition to the seven global needs listed above, namely: i) improved control of the sweetpotato weevil; ii) cultivars with high $\beta$-carotene content to address vitamin A deficiency; iii) improvements to sweetpotato propagation systems and storage methods (in addition to improvements in availability and quality listed above); iv) cultivars tolerant to drought and marginal soil conditions; v) cultivars providing high yield as animal fodder as well as food; vi) improved management of soil fertility and cropping systems; vii) improved harvesting methods for sweetpotato; and viii) better evidence on the economic rate of return to sweetpotato research and development. Respondents from China, on the other hand, listed as top-priority needs (in addition to the seven global needs listed above): i) conservation and characterization of sweetpotato genetic resources; ii) prebreeding; iii) cultivars with high starch yield; iv) new food products from sweetpotato; and v) improved capacity in using information and communication technologies.

The regional differences in priorities for sweetpotato improvement reflect not only differences in the role of sweetpotato in the rural economies but also different capacities of the agricultural research systems. China, with its relatively strong agricultural research system, put greater importance on long-term research strategies, like improving utilization of genetic resources and prebreeding. It also put greater importance on enabling sweetpotato farmers to meet the growing market demand for industrial starch and diverse consumer food products. And, given the size of China and its rapidly growing ICT infrastructure, the sweetpotato research community expressed a strong need to strengthen their capacity in utilization of these tools for acquiring and disseminating new crop technology and information. Africa, on the other hand, placed higher priority on more nearterm applied research to improve cultivars and crop management methods suitable to local environmental conditions and, importantly, propagation systems to disseminate new varieties and reduce crop losses from viruses.

The priority needs identified in this survey differ in some important ways from the results of an earlier global survey on sweetpotato productivity constraints conducted by CIP in 1990 (unpublished data, CIP). The two surveys are not directly comparable as they posed different questions (or worded questions on similar topics differently) and had different geographic coverage (14 of the 24 countries in the 1990 survey were from Latin America, and no responses were received from China, the leading producer of the crop). Nevertheless, some general compari- sons can be drawn. One major difference is that in the 1990 survey, three of the top four needs referred to collection, conservation, and characterization of sweetpotato genetic resources. In the 2005 survey, genetic resources were ranked in the second tier of global priorities. This may reflect progress made in the management of genetic resources in the intervening years. By the mid-1990s, global ex situ genebank collections contained more than 32,000 sweetpotato accessions, with $\approx 21 \%$ held by CIP (FAO, 1997). The need for improved postharvest utilization and marketing was ranked high in the 1990 survey as it was in the 2005 survey. But among survey respondents from subSaharan Africa, postharvest needs scored relatively low in 1990. It appears that the need to expand marketing and employment opportunities for sweetpotato farmers may have increased substantially in at least some parts of Africa. Other priorities that were ranked high in 1990 and that were still top-ranked global priorities in 2005 are the needs to control virus diseases and to improve availability and quality of planting material of sweetpotato. Although substantial progress was achieved in reducing the virus constraint in China (see Fuglie et al., 1999), it appears that much remains to be done here as well as other regions of the world.

The growing importance of sweetpotato as a food staple in Africa, and its continued importance in Asia even as consumers reduced direct consumption, attests to the significant role that the sweetpotato crop has played in meeting the food, fodder, and income needs of the world's poorest and fastest-growing populations. Further improvements to the sweetpotato that could be made through research to address the needs expressed by the survey respondents will no doubt help this crop to continue to make significant contributions to improving the livelihoods of farm households in developing countries.

\section{Literature Cited}

Alston, J.M., G.W. Norton, and P.G. Pardey. 1995. Science under scarcity: principles and practice for agricultural research evaluation and priority setting. Cornell University Press, Ithaca, NY.

CIP. 2004. The CIP vision: preserving the core, stimulating progress. Intl. Potato Ctr., Lima, Peru.

FAO. 1997. The state of the world's plant genetic resources for food and agriculture. Food and Agriculture Organization of the United Nations, Rome, Italy.

FAO. 2005. FAOSTAT database. July 2005. <http:// faostat.fao.org/>. Food and Agriculture Organization of the United Nations, Rome, Italy.
Fuglie, K. 2007. Research priority assessment for the CIP 2005-2015 strategic plan: projecting impacts on poverty, employment, health and the environment. Impact Enhancement Div., Intl. Potato Ctr., Lima, Peru.

Fuglie, K., S. Mahalaya, and F. Suri. 2002. The economics of sweetpotato genetic resource conservation and varietal improvement in Asia, p. 79-122. In: R. Rao and D. Campilan (eds.). Exploring the complementarities of in situ and ex situ conservation strategies for Asian sweetpotato genetic resources. Intl. Plant Genet. Resources Inst. Reg. Office for Asia, the Pacific and Oceania, Serdang, Malaysia.

Fuglie, K., L. Zhang, L.F. Salazar, and T.S. Walker. 1999. Economic impact of virus-free sweet potato planting material in Shandong Province, China. Intl. Potato Ctr., Lima, Peru.

Gardner, B. and W. Lesser. 2003. International agricultural research as a global public good. Amer. J. Agr. Econ. 85(3):692-697.

Gibson, R., R. Mwanga, S. Kasule, S. Fuentes, and E. Carey. 1996. Sweetpotato feathery mottle and other viruses in Uganda, p. 87-90. Proc. Reg. Sweetpotato Wkshp., 9-13 Jan. 1996, Gabon.

Horton, D. 1989. Constraints to sweet potato production and use, p. 219-223. Paper presented at the Wkshp. on Sweet Potato Improvement in Asia, Trivandrum, India, 1989. Intl. Potato Ctr., Lima, Peru.

Huang J., J. Song, F. Qiao, and K. Fuglie. 2003. Sweetpotato in China: economic aspects and utilization in pig production. Intl. Potato Ctr., Bogor, Indonesia.

Low, J., T. Walker, and R. Hijmans. 2001. The potential impact of orange-flesh sweetpotatoes on vitamin A intake in sub-Saharan Africa, p. 16. (2202-063-E). Paper presented at Reg. Wkshp. on Food-Based Approaches to Human Nutritional Deficiencies: The VITAA Project, Vitamin A and Orange Fleshed Sweetpotato in Sub-Saharan Africa, 9-11 May 2001, Nairobi, Kenya.

Maza, N., A. Morales, O. Ortiz, P. Winters, J. Alcázar, and G. Scott. 2000. El impacto del manejo integrado del tetuán del boniato (Cylas formicarius Fab.) en Cuba. Intl. Potato Ctr., Lima, Peru.

Moyer, J. and L. Salazar. 1989. Viruses and viruslike diseases of sweet potato. Plant Dis. 73:451-455.

Ruttan, V.W. 1982. Agricultural research policy. University of Minnesota Press, St. Paul.

Smit, N. and B. Odongo. 1997. Integrated pest management for sweetpotato in East Africa. Program Rpt. 1995-1996, p. 191-197. Intl. Potato Ctr., Lima, Peru.

Walker, T. and K. Fuglie. 2006. Prospects for enhancing value of crops through public-sector research: lessons from experiences with roots and tubers. Social Sci. Working Paper 2006-1. Intl. Potato Ctr., Lima Peru.

Woolfe, J. 1992. Sweetpotato: an untapped food resource. Cambridge University Press, Cambridge, U.K.

World Bank. 2005. WDI on line. World Bank, Washington, D.C. $<$ https://publications. worldbank.org/>. 